\title{
Assessing Factors Influencing the Purchase Decision of Cosmetics among Middle Class Female Muslims
}

\author{
Fatimah Zahra Nasution \#1, Andina Eka Mandasari \#2, Muwahhid Billah \#3 \\ ${ }^{\#}$ Department of Economics, Siliwangi University \\ Tasikmalaya, Indonesia \\ Ifatimahzahranasution@unsil.ac.id
}

\begin{abstract}
Indonesia witnessed significant demographic and economic change over the past few decades. The share of women participating in formal employment continues to increase with improvement in women's access to formal education. These and other changes have influenced consumption patterns. This study investigates the effect of price, Halal labelling and product suitability to different skin types on decisions to purchase cosmetics among formally employed middle class women using female Muslim academicians as a case study. Primary data were gathered through questionnaires. Cronbach's Alpha was run to assess the reliability and validity of the study instrument. Findings show that price has no significant effect on purchasing decisions while Halal labelling and product suitability were found to significantly influence purchasing decisions.
\end{abstract}

Keywords - Middle Class Female Muslim, Halal Cosmetics, Purchasing Decision.

\section{INTRODUCTION}

Islam is a complete way of life in which principles and orders are clearly defined for every Muslim to follow. Halal (sanctioned by Islamic Law) is one of the principles to be ensured in the consumption, usage, or application of products. As much as guidelines for permitted food to ensure purity, cosmetics that are applied to the body for cleansing and beautifying or modifying the body should be used without harming the body and made from acceptable material. For Muslims, it is essential to ensure that cosmetic products are sharia- compliant since purity is compulsory in performing daily prayers.

The rise in awareness about Halal product has increased the demand for Halal products in today's market. The purpose of this study is to investigate the real effect of price, Halal labelling and product suitability to different skin types on purchasing decision of cosmetics among middle class female Muslims. Additionally, attempts were made to identify which of the analyzed variables affects the most.
It is interesting to analyze factors affecting consumer behavior in purchasing Halal cosmetics. The results of this research can be used to enhance the ideas, thoughts and better understanding of the influencing factors towards purchasing decision of Halal cosmetics among middle class female Muslims. With high level of education, the respondents would be more rational and caring about the importance of purchasing Halal products.

The remainder of this paper comprises of the following 3 sections: the next section addresses literature review, data collection, treatment and analysis and is followed by a section that presents and discusses findings from the study. The paper ends with a concluding section.

\section{LITERATURE REVIEW}

One essential factor that has been considered in many exchange relationships is price, which is the financial value that is given out in exchange for a product. Price determines what amount a buyer is willing to pay in return for the product. Price satisfaction has become an important factor which influences buyer in deciding the purchase of a cosmetic product. [1] Price satisfaction has significant influence to purchase decision. [2]

Apart from price factor, improving awareness levels about Halal products has increased their demand. Attitude towards Halal products will positively influence intention to choose Halal products. [3] Studies show that awareness and usage of Halal labelled food, cosmetics and personal care products has been increasing significantly [4][5]. Abd Aziz and Wahab, have identified knowledge, purity and safety as significant factors influencing the consumers to buy Halal cosmetics. [6]. The content or the ingredient of the cosmetic product is the most important factor 
that may influence them to consume the cosmetic product. [7] Consumers identify Halal products through explicit Halal labels or logos on the package. [8] Thus, Halal certified brands of cosmetics positively influence the purchase decision [9].

It is important to analyze factors affecting consumer behavior in purchasing Halal cosmetics. There is a significant relationship between knowledge and religiosity on attitude towards Halal products [4] [10] Knowledge drives attitude of individuals to make better choices in life.[11] Improvement in knowledge about Halal products generates higher demand resulting in a growing Halal cosmetics sector and growth in revenue for producers, all other things remaining the same. Improving access to education and increase in the share of women attaining higher levels of education also contribute to the demand of safe and quality of Halal cosmetic products [12] This is in line with the finding that socio-cultural factors like behavior and believe determine the purchase decision of cosmetics products. [13]

In purchasing cosmetics, a rational buyer will consider the suitability of the product to her skin types. If a product fulfils the buyer's expectations, she will be pleased and consider that the product is of acceptable or even high quality. If the expectations are not fulfilled, the customer will consider that the product is of low quality and discontinue the using. Product suitability of cosmetics comprises of texture, results and pleasant experience with the cosmetics.

This study examines the behavior of female Muslim academics in purchasing cosmetics. Academics were selected for the case study as a proxy of educated middle class consumers consistent with improving literacy level and consumption patterns in the country. We assumed that as an academician with high level of education, the respondents would be more rational and caring about the importance of purchasing Halal products. This study takes price, Halal labelling and product suitability to skin types as important exogenous variables (among others) that influence the decision to purchase cosmetics, the endogenous variable. Path diagram describing the effect of exogenous variables $(\mathrm{X} 1, \mathrm{X} 2, \mathrm{X} 3)$ to endogenous variable $(\mathrm{Y})$ is presented on the diagram 1.

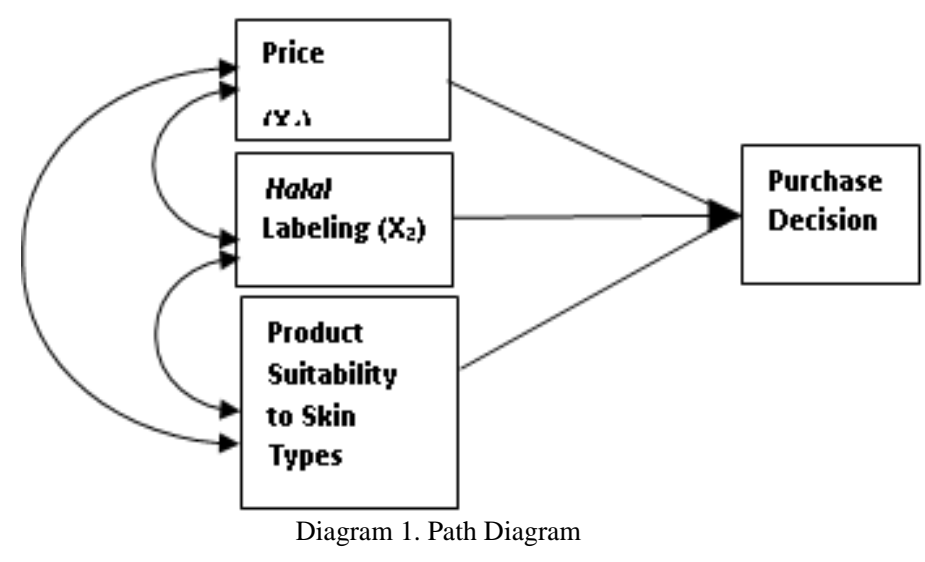

III. METHOD AND DATA

\section{A. Method}

Survey method was used in this study whereas primary data was collected directly. In obtaining the effect of price, Halal labelling and product suitability to skin types on the purchase decision, Path analysis method was run. Path analysis aimed to explain the real direct and indirect effect of variables as the exogenous variable and endogenous one. SPSS 16.0 was used to analyze the data.

\section{B. Data}

This study used quantitative approach based on primary data gathered through questionnaires from 53 female Muslim academicians from 7 faculties of Siliwangi University. Proportionate stratified random sampling and the Slovin formula were used in drawing respondents and determining sample size respectively. Table 1 presents an overview of sample characteristics. The questionnaire was pilot tested to ensure acceptability with respondents and efficiency in collecting data.

According to the respondents' profiles, the study found the majority $(52.83 \%)$ were above 35-year age group, $92.45 \%$ of the respondents were married, and earning a monthly income of IDR 5,000,000 to $30,000,000(52,83 \%)$. As much as $66.04 \%$ admitted that they used Wardah Cosmetics, $18.87 \%$ used Viva Cosmetics, and $15.09 \%$ used other brands like Sariayu, Revlon, La Tulipe, Zoya and Mustika Ratu. 
TABLE 1.

SAMPLE CHARACTERISTICS

\begin{tabular}{|c|c|c|c|}
\hline CHARACTERISTICS & CATEGORY & $\mathbf{F}$ & $\%$ \\
\hline \multirow[t]{8}{*}{ FACULTY } & Faculty of Education & 13 & $24.53 \%$ \\
\hline & Faculty of Economics & 13 & $24.53 \%$ \\
\hline & $\begin{array}{l}\text { Faculty of Health } \\
\text { Sciences }\end{array}$ & 10 & $18.87 \%$ \\
\hline & $\begin{array}{l}\text { Faculty of } \\
\text { Agriculture }\end{array}$ & 7 & $13.21 \%$ \\
\hline & \begin{tabular}{|l} 
Faculty of \\
Engineering
\end{tabular} & 6 & $11.32 \%$ \\
\hline & $\begin{array}{l}\text { Faculty of Social and } \\
\text { Political Sciences }\end{array}$ & 2 & $3.77 \%$ \\
\hline & $\begin{array}{l}\text { Faculty of Islamic } \\
\text { Studies }\end{array}$ & 2 & $3.77 \%$ \\
\hline & Total & 53 & $100 \%$ \\
\hline \multirow[t]{4}{*}{ AGE DISTRIBUTION } & $>35$ years old & 28 & $52.83 \%$ \\
\hline & $30-35$ years old & 14 & $26.42 \%$ \\
\hline & $24-29$ years old & 11 & $20.75 \%$ \\
\hline & Total & 53 & $100 \%$ \\
\hline \multirow[t]{3}{*}{ MARITAL STATUS } & Married & 49 & $92.45 \%$ \\
\hline & Unmarried & 4 & $7.55 \%$ \\
\hline & Total & 53 & $100 \%$ \\
\hline \multirow[t]{5}{*}{$\begin{array}{l}\text { RESPONDENTS } \\
\text { EXPENDITURE } \\
\end{array}$} & $\begin{array}{l}\text { IDR. } 5,000,000- \\
\text { IDR. } 30,000,000\end{array}$ & 28 & $52.83 \%$ \\
\hline & $\begin{array}{l}\text { IDR. } 1,000,000- \\
\text { IDR. 5,000,000 }\end{array}$ & 23 & $43.39 \%$ \\
\hline & $<$ IDR. $1,000,000$ & 1 & $1.89 \%$ \\
\hline & $>$ IDR. $30,000,000$ & 1 & $1.89 \%$ \\
\hline & Total & 53 & $100 \%$ \\
\hline \multirow[t]{4}{*}{ COSMETIC BRANDS } & Wardah & 35 & $66.04 \%$ \\
\hline & Viva & 10 & $18.87 \%$ \\
\hline & Others & 8 & $15.09 \%$ \\
\hline & Total & 53 & $100 \%$ \\
\hline
\end{tabular}

\section{VALIDITY AND RELIABILITY ANALYSIS}

Prior to analyzing the data, the instrument was tested to ensure validity and reliability of test items. The validity and reliability testing results of all instrument for price (X1), Halal labelling (X2) and product suitability (X3) and purchasing decision (Y) with the standard of error, $\alpha=0.05$. Cronbach's Alpha was used for validity and reliability tests. Cronbach's alpha assesses the consistency of an instrument's components and subcomponents. The reliability and validity testing of the instrument was done using SPSS with significance level $(\alpha)$ and sample size (n) of 0.05 and 53 respectively. Table 2 shows that the Corrected Item-Total Correlation for 8 items was less than the computed Cronbach's threshold value $(0,297)$ and were excluded from the study. Table 3 shows retest results that confirm the validity of the remaining items that were subsequently used for the study.
TABLE 2.

VALIDITY AND RELIABILITY TESTS

\begin{tabular}{|c|c|c|c|}
\hline $\begin{array}{l}\text { Instrument } \\
\text { Variable }\end{array}$ & $\begin{array}{l}\text { Cronbach } \\
\text { 's Alpha }\end{array}$ & $\begin{array}{l}\text { Corrected Item-Total } \\
\text { Correlation }\end{array}$ & $\begin{array}{l}\text { Conclusio } \\
\text { n }\end{array}$ \\
\hline Price & 0,558 & & Reliable \\
\hline H1 & & 0.445 & Valid \\
\hline $\mathrm{H} 2$ & & 0.423 & Valid \\
\hline H3 & & 0.483 & Valid \\
\hline $\mathrm{H} 4$ & & 0.274 & invalid \\
\hline H5 & & 0.090 & invalid \\
\hline $\begin{array}{l}\text { Halal } \\
\text { Labeling }\end{array}$ & 0,754 & & Reliable \\
\hline LH1 & & 0.264 & invalid \\
\hline $\mathrm{LH} 2$ & & 0.509 & Valid \\
\hline LH3 & & 0.291 & Valid \\
\hline LH4 & & 0.620 & Valid \\
\hline LH5 & & 0.451 & Valid \\
\hline LH6 & & 0.528 & Valid \\
\hline LH7 & & 0.508 & Valid \\
\hline LH8 & & 0.393 & Valid \\
\hline LH9 & & 0.509 & Valid \\
\hline $\begin{array}{l}\text { Prod. } \\
\text { Suitability }\end{array}$ & 0,848 & & Reliable \\
\hline KePro1 & & 0.618 & Valid \\
\hline KePro2 & & 0.695 & Valid \\
\hline KePro3 & & 0.753 & Valid \\
\hline KePro4 & & 0.702 & Valid \\
\hline $\begin{array}{l}\text { Purchase } \\
\text { Decision }\end{array}$ & 0,385 & & Reliable \\
\hline KP1 & & 0.031 & invalid \\
\hline KP2 & & 0.289 & Valid \\
\hline KP3 & & 0.316 & Valid \\
\hline KP4 & & 0.334 & Valid \\
\hline KP5 & & 0.448 & Valid \\
\hline KP6 & & 0.477 & Valid \\
\hline KP7 & & 0.385 & Valid \\
\hline KP8 & & -0.407 & invalid \\
\hline KP9 & & 0.150 & invalid \\
\hline KP10 & & 0.440 & Valid \\
\hline KP11 & & -0.153 & invalid \\
\hline KP12 & & -0.009 & invalid \\
\hline
\end{tabular}


The reliability and validity testing were conducted through Cronbach's Alpha with the criteria that item greater than or equal as $r$ table as the reliable condition; correlation coefficient is between indicator value greater than or equal to $r$ table as the validity condition. In this study, $\alpha=$ 0.05 and $n=53$, thus $r$ table is valued 0.297. The reliability and validity testing of the instrument used SPSS package version 16.0. Based on table 2, it is stated that all Cronbach's Alpha valued greater than or equal to 0.297. All of the variables have fulfilled reliability criteria. The validity testing shows that some of the Corrected Item-Total Correlation is greater than or equal to 0.297. Item H4, H5, LH1, KP1, KP8, KP9, KP11, and KP12 do not fulfil the validity criteria, as the consequence, those 8 instruments were excluded from the analysis. The following table 3 shows the results of validity and reliability retesting whereas items $\mathrm{H} 4$, H5, LH1, KP1, KP8, KP9, KP11, and KP12 were excluded.

TABLE 3.

VALIDITY AND RELIABILITY TEST RESULTS AFTER EXLUSION

\begin{tabular}{|l|l|l|l|}
\hline $\begin{array}{l}\text { Variable } \\
\text { instruments }\end{array}$ & $\begin{array}{l}\text { Cronbach } \\
\text { Alpha }\end{array}$ & $\begin{array}{l}\text { Corrected Item- } \\
\text { Total Correlation }\end{array}$ & Conclusion \\
\hline Price & 0,723 & & Reliable \\
\hline H1 & & 0.532 & Valid \\
\hline H2 & 0.637 & Valid \\
\hline H3 & 0.583 & Valid \\
\hline Halal Label & 0,759 & & Reliable \\
\hline LH2 & & 0.546 & Valid \\
\hline LH4 & & 0.569 & Valid \\
\hline LH5 & & 0.388 & Valid \\
\hline LH6 & 0.550 & Valid \\
\hline LH7 & & 0.478 & Valid \\
\hline LH8 & 0.416 & Valid \\
\hline LH9 & & 0.563 & Valid \\
\hline Prod. Suitability & 0,848 & & Reliable \\
\hline KePro1 & & 0.618 & Valid \\
\hline KePro2 & & 0.695 & Valid \\
\hline KePro3 & & 0.753 & Valid \\
\hline KePro4 & & 0.702 & Valid \\
\hline
\end{tabular}

TABLE 3. CONT
\begin{tabular}{|l|l|l|l|}
\hline $\begin{array}{l}\text { Purchase } \\
\text { Decision }\end{array}$ & 0,729 & & Reliable \\
\hline KP2 & & 0.511 & Valid \\
\hline KP3 & & 0.544 & Valid \\
\hline KP4 & & 0.401 & Valid \\
\hline KP5 & & 0.521 & Valid \\
\hline KP6 & & 0.537 & Valid \\
\hline KP7 & & 0.478 & Valid \\
\hline KP10 & & 0.322 & Valid \\
\hline
\end{tabular}

Based on table 3, all of the Cronbach's Alpha values are greater than or equal to 0.297 and the values of Corrected Item-Total Correlation are greater than or equal to 0.297 , therefore, it can be concluded that all items of the research instrument are reliable and valid. Accordingly, instruments of variable Price (X1), Halal Labelling (X2), Product Suitability to Skin Types (X3), and Purchase Decision (Y) can be used for the next step of analysis.

\section{RESULTS AND DISCUSSION}

\section{A. Responses on Price}

To digest and analyze the respondent's answers regarding price, Halal labelling, product suitability to skin types and purchase decision on cosmetics used, the result of primary data will be discussed in this section. Respondents answers were obtained from the calculation of the interval score level for each price, Halal labelling, product suitability to skin types and purchase decision indicators. The calculation of the value for each indicator is as follow:

Highest score : $53 \times 5=265$

Lowest score : $53 \times 1=53$

Items of statement criteria $=5$

$$
\begin{aligned}
& \text { Interval score level }=\frac{\text { highest } \text { score }- \text { lowest score }}{\text { items of statement criteria }} \\
& =\frac{265-53}{5}=42.4
\end{aligned}
$$

Thus, classification of the interval score level for each indicator of price, Halal labelling and product suitability to skin types and purchase decision is presented on table 4: 
TABLE 4.

INTERVAL SCORE LEVEL

\begin{tabular}{|l|l|}
\hline \multicolumn{1}{|c|}{ Score } & Interval Score Level \\
\hline $53-95.35$ & Very Bad \\
\hline $95.4-137.75$ & Bad \\
\hline $137.8-180.15$ & Good Enough \\
\hline $180.2-222.55$ & Good \\
\hline $222.6-265$ & Very Good \\
\hline
\end{tabular}

Based on table 4, the indicator criteria of variable $\mathrm{X} 1$ (price) is shown on table 5:

TABLE 5.

INDICATOR CRITERIA OF PRICE

\begin{tabular}{|c|c|c|c|c|c|}
\hline No. & Indicator & Ta & etted Score & $\begin{array}{l}\text { Achieve } \\
\text { Score }\end{array}$ & Criteria \\
\hline 1 & $\begin{array}{l}\text { Association of price to } \\
\text { financial capability }\end{array}$ & 53 & $X 5=265$ & 234 & $\begin{array}{l}\text { Very } \\
\text { Good }\end{array}$ \\
\hline 2 & $\begin{array}{l}\text { Preference to purchase th } \\
\text { cosmetics lower price }\end{array}$ & 53 & X $5=265$ & 159 & $\begin{array}{l}\text { Good } \\
\text { Enough }\end{array}$ \\
\hline 3 & $\begin{array}{l}\text { Preference to purchase } \\
\text { when there is discount }\end{array}$ & 53 & $X 5=265$ & 183 & good \\
\hline 4 & $\begin{array}{l}\text { Preference to purchase } \\
\text { cosmetics with flexible } \\
\text { way of payment }\end{array}$ & 53 & X $5=265$ & 238 & $\begin{array}{l}\text { Very } \\
\text { good }\end{array}$ \\
\hline 5 & $\begin{array}{l}\text { Affordability to Halal } \\
\text { labelled cosmetics }\end{array}$ & 53 & $X 5=265$ & 234 & $\begin{array}{l}\text { Very } \\
\text { good }\end{array}$ \\
\hline & Total & & & 1048 & \\
\hline
\end{tabular}

Highest score of price : $53 \times 5 \times 5=1325$

Lowest score of price : $53 \times 1 \times 5=265$

Items of statement criteria : 5

Interval score level $=\frac{1325-265}{5}=212$

Thus, rating classification for price is shown on table 6.

TABLE 6.

RATING CLASSIFICATION FOR PRICE IN TOTAL

\begin{tabular}{|l|l|}
\hline Score & Interval Score Level \\
\hline $265-476$ & Very Bad \\
\hline $477-688$ & Bad \\
\hline $689-900$ & Good Enough \\
\hline $901-1112$ & Good \\
\hline $1113-1325$ & Very Good \\
\hline
\end{tabular}

The value obtained from analysis on respondents answer of price is as much as 1048 which represents criteria of good. This reveals that all indicators of price of the cometics used are in good classification. It can be inferred that female Muslim academicians in Siliwangi University purchase the cosmetics in accordance with their financial capability, the flexible way of payment and affordability to Halal labelled cosmetics. Lower prices and discount offered do not induce the purchasing.

\section{B. Responses on Halal Label}

Based on table 4 , the indicator criteria of variable X2 (Halal labelling) is shown on table 7:

TABLE 7.

INDICATOR CRITERIA OF HALAL LABELING

\begin{tabular}{|c|c|c|c|c|}
\hline No. & Indicator & $\begin{array}{l}\text { Targeted } \\
\text { Score }\end{array}$ & $\begin{array}{l}\text { Achieved } \\
\text { score }\end{array}$ & Criteria \\
\hline 1 & $\begin{array}{l}\text { Understanding the } \\
\text { label of "Halal" in } \\
\text { general }\end{array}$ & $\begin{array}{l}53 \times 5= \\
265\end{array}$ & 257 & $\begin{array}{l}\text { Very } \\
\text { Good }\end{array}$ \\
\hline 2 & $\begin{array}{l}\text { The appearance of the } \\
\text { label "Halal" on } \\
\text { cosmetics products }\end{array}$ & $\begin{array}{l}53 \times 5= \\
265\end{array}$ & 195 & Good \\
\hline 3 & $\begin{array}{l}\text { The writing "Halal" of } \\
\text { the label is readable }\end{array}$ & $\begin{array}{l}53 \times 5= \\
265\end{array}$ & 251 & $\begin{array}{l}\text { Very } \\
\text { Good }\end{array}$ \\
\hline 4 & $\begin{array}{l}\text { The "Halal" label helps } \\
\text { in identifying the Halal } \\
\text { quality of the cosmetics } \\
\text { product }\end{array}$ & $\begin{array}{l}53 \times 5= \\
265\end{array}$ & 242 & $\begin{array}{l}\text { Very } \\
\text { Good }\end{array}$ \\
\hline 5 & $\begin{array}{l}\text { The combination of the } \\
\text { image illustration and } \\
\text { the writing on the label } \\
\text { is "Halal" label which } \\
\text { is approved by BPPOM } \\
\text { MUI }\end{array}$ & $\begin{array}{l}53 \times 5= \\
265\end{array}$ & 241 & $\begin{array}{l}\text { Very } \\
\text { Good }\end{array}$ \\
\hline 6 & $\begin{array}{l}\text { The existence of Halal } \\
\text { Label on the product } \\
\text { becomes significant } \\
\text { consideration in the } \\
\text { purchase decision }\end{array}$ & $\begin{array}{l}53 \times 5= \\
265\end{array}$ & 222 & Good \\
\hline 7 & $\begin{array}{l}\text { "Halal" label on the } \\
\text { packaging makes it } \\
\text { easy in having } \\
\text { information about the } \\
\text { Halal status of the } \\
\text { cosmetics product. }\end{array}$ & $\begin{array}{l}53 \times 5= \\
265\end{array}$ & 244 & $\begin{array}{l}\text { Very } \\
\text { Good }\end{array}$ \\
\hline 8 & $\begin{array}{l}\text { The confidence that the } \\
\text { "Halal" label is } \\
\text { irremovable }\end{array}$ & $\begin{array}{l}53 \times 5= \\
265\end{array}$ & 225 & $\begin{array}{l}\text { Very } \\
\text { Good }\end{array}$ \\
\hline 9 & $\begin{array}{l}\text { Due to its irremovable, } \\
\text { the "Halal" label on the } \\
\text { packaging stimulates } \\
\text { the buyer to purchase } \\
\text { the product. }\end{array}$ & $\begin{array}{l}53 \times 5= \\
265\end{array}$ & 228 & $\begin{array}{l}\text { Very } \\
\text { Good }\end{array}$ \\
\hline & Total & & 2105 & \\
\hline
\end{tabular}


Highest score of Halal labelling: 53 x 5 x $9=2385$

Lowest score of Halal labelling: 53 x 1 x $9=477$

Items of statement criteria: 5

Interval score level $=\frac{2385-477}{5}=381.6$

Thus, rating classification of Halal labelling is shown on table 8 .

TABLE 8.

RATING CLASSIFICATION OF HALAL LABELING

\begin{tabular}{|l|l|}
\hline Score & Interval Score Level \\
\hline $477-858.55$ & Very Bad \\
\hline $858.6-1240.15$ & Bad \\
\hline $1240.2-1621.75$ & Good Enough \\
\hline $1621.8-2003.35$ & Good \\
\hline $2003.4-2385$ & Very Good \\
\hline
\end{tabular}

The value obtained from analysis on respondents answer of "Halal" labelling is as much as 2105 which represents criteria of very good. This reveals that all indicators of "Halal" Labelling of the cosmetics used are in very good classification. It can be inferred that female Muslim academicians in Siliwangi University observe and understand the meaning of "Halal" label on cosmetic product purchased. Besides, the respondents are confident that the label is irremovable.

\section{Responses on Product Suitability to Skin Types}

Based on table 4, the indicator criteria of variable $\mathrm{X} 3$ (Product Suitability to Skin Types) is shown on table 9:

TABLE 9.

INDICATOR CRITERIA OF PRODUCT SUITABILITY TO SKIN TYPES

\begin{tabular}{|c|c|c|c|c|}
\hline No. & Indicator & $\begin{array}{l}\text { Targetted } \\
\text { Score }\end{array}$ & $\begin{array}{l}\text { Achieved } \\
\text { Score }\end{array}$ & $\begin{array}{l}\text { Criteri } \\
\text { a }\end{array}$ \\
\hline 1 & $\begin{array}{l}\text { The texture of the } \\
\text { cosmetic products give } \\
\text { delicate/pleasant feeling } \\
\text { while used }\end{array}$ & $\begin{array}{r}53 \\
265\end{array}$ & 234 & $\begin{array}{l}\text { Very } \\
\text { Good }\end{array}$ \\
\hline 2 & $\begin{array}{l}\text { The result of cosmetics } \\
\text { present as the promise. }\end{array}$ & $\begin{array}{rrr}53 & \times \quad 5= \\
265 & & \end{array}$ & 214 & Good \\
\hline 3 & $\begin{array}{l}\text { Having pleasant } \\
\text { experience while using } \\
\text { the cosmetic products. }\end{array}$ & $\begin{array}{r}53 \\
265\end{array}$ & 216 & Good \\
\hline \multirow[t]{2}{*}{4} & $\begin{array}{l}\text { Cosmetics used are } \\
\text { suitable with skin types. }\end{array}$ & $\begin{array}{r}53 \\
265\end{array}$ & 224 & $\begin{array}{l}\text { Very } \\
\text { Good }\end{array}$ \\
\hline & Total & & 888 & \\
\hline
\end{tabular}

Highest score of Product Suitability to Skin Types: 53 × 5 x $4=1060$

Lowest score of Product Suitability to Skin Types: $53 \times 1 \times 4=212$

Items of statement criteria: 5

Interval score level $=\frac{1060-212}{5}=169.6$

Thus, rating classification of Product Suitability to Skin Types is shown on table 10.

TABLE 10 .

RATING CLASSIFICATION OF PRODUCT SUITABILITY TO SKIN TYPES

\begin{tabular}{|l|l|}
\hline Score & Interval Score Level \\
\hline $212-381.55$ & Very Bad \\
\hline $381.6-551.15$ & Bad \\
\hline $551.2-720.75$ & Good Enough \\
\hline $720.8-890.35$ & Good \\
\hline $890.4-1060$ & Very Good \\
\hline
\end{tabular}

The value obtained from analysis on respondents answer of product suitability to skin types is as much as 888 which represents criteria of good. This reveals that all indicators of product suitability to skin types of the cosmetics used are in good classification. It can be inferred that the texture of cosmetic products used is suitable with skin types of female Muslim academicians in Siliwangi University, thus they experience comfortable feeling when using the cosmetic products.

\section{Responses on Purchase Decision}

Based on table 4, the indicator criteria of variable $\mathrm{Y}$ (Purchase Decision) is shown on tabel 11.

TABLE 11.

INDICATOR CRITERIA OF PURCHASE DECISION

\begin{tabular}{|l|l|c|c|c|}
\hline No. & \multicolumn{1}{|c|}{ Indicator } & $\begin{array}{c}\text { Targetted } \\
\text { Score }\end{array}$ & $\begin{array}{c}\text { Achieved } \\
\text { Score }\end{array}$ & Criteria \\
\hline 1 & $\begin{array}{l}\text { Purchasing the } \\
\text { cosmetic products } \\
\text { based on personal } \\
\text { needs. }\end{array}$ & 53 X 5=265 & 240 & $\begin{array}{l}\text { Very } \\
\text { good }\end{array}$ \\
\hline 2 & $\begin{array}{l}\text { Seeking for } \\
\text { information of the } \\
\text { products prior to } \\
\text { deciding the } \\
\text { purchase. }\end{array}$ & 53 X 5=265 & 205 & Good \\
\hline
\end{tabular}


TABLE 11. CONT.

\begin{tabular}{|c|c|c|c|c|}
\hline 3 & $\begin{array}{l}\text { Persuade others to } \\
\text { buy certain } \\
\text { cosmetics. }\end{array}$ & $53 \times 5=265$ & 155 & $\begin{array}{l}\text { Good } \\
\text { Enough }\end{array}$ \\
\hline 4 & $\begin{array}{l}\text { Purchase cosmetic } \\
\text { products of various } \\
\text { brands. }\end{array}$ & $53 \times 5=265$ & 142 & $\begin{array}{l}\text { Good } \\
\text { Enough }\end{array}$ \\
\hline 5 & $\begin{array}{l}\text { Satisfaction on } \\
\text { purchased } \\
\text { cosmetics with } \\
\text { specific brand. }\end{array}$ & $53 \times 5=265$ & 226 & $\begin{array}{l}\text { Very } \\
\text { good }\end{array}$ \\
\hline 6 & $\begin{array}{l}\text { Comparing similar } \\
\text { typed cosmetics of } \\
\text { various brands. }\end{array}$ & $53 \times 5=265$ & 155 & $\begin{array}{l}\text { Good } \\
\text { Enough }\end{array}$ \\
\hline 7 & $\begin{array}{l}\text { Availability of } \\
\text { preferred cosmetics } \\
\text { brand in any shops }\end{array}$ & $53 \times 5=265$ & 231 & $\begin{array}{l}\text { Very } \\
\text { good }\end{array}$ \\
\hline 8 & $\begin{array}{l}\text { Purchasing } \\
\text { cosmetics only in } \\
\text { particular shop }\end{array}$ & $53 \times 5=265$ & 163 & $\begin{array}{l}\text { Good } \\
\text { enough }\end{array}$ \\
\hline 9 & $\begin{array}{l}\text { Purchasing } \\
\text { cometics on regular } \\
\text { basis }\end{array}$ & $53 \times 5=265$ & 215 & Good \\
\hline 10 & $\begin{array}{l}\text { Purchasing } \\
\text { cosmetics } \\
\text { repeteadly }\end{array}$ & $53 \times 5=265$ & 222 & Good \\
\hline 11 & $\begin{array}{l}\text { Purchasing } \\
\text { cosmetics in } \\
\text { limited amount }\end{array}$ & $53 \times 5=265$ & 209 & Good \\
\hline 12 & $\begin{array}{l}\text { Purchasing } \\
\text { cosmetics in } \\
\text { relativey great } \\
\text { amount especially } \\
\text { for stock/inventory. }\end{array}$ & $53 \times 5=265$ & 104 & $\mathrm{Bad}$ \\
\hline & Total & & 2267 & \\
\hline
\end{tabular}

Highest score of purchase decision : $53 \times 5 \times 12=$ 3180

Lowest score of purchase decision: $53 \times 1 \times 12=$ 636

Items of statement criteria : 5

Interval score level $=\frac{3180-636}{5}=508.8$

Thus, rating classification of purchase decision is shown on table 12 .
TABLE 12.

RATING CLASSIFICATION OF PURCHASE DECISION

\begin{tabular}{|c|c|}
\hline Score & Interval Score Level \\
\hline $636-1144.75$ & Very Bad \\
\hline $1144.8-1653.55$ & Bad \\
\hline $1653.6-2162.35$ & Good Enough \\
\hline $2162.4-2671.15$ & Good \\
\hline $2671.2-3180$ & Very Good \\
\hline
\end{tabular}

The value obtained from analysis on respondents answer of purchase decision is as much as 2267 which represents criteria of good. This reveals that all indicators of purchase decision of the cometics used are in good classification. It can be inferred that female Muslim academicians in Siliwangi University purchase the cosmetic products on the basis of personal needs whereas the products are available in many shops, the respondent feel satisfied with the produtcs used. Nevertheless, the respondents only buy in limited amount.

E. The Effect of Price, Halal Label, and Product Suitability to Skin Types on Purchase Decision of Cosmetic Products Used.

The discussion of the result of this study analyzes three exogenous variables. To discover the magnitude of the effect of Price (X1), Halal Labeling (X2), Product Suitability to Skin Types (X3) on Purchase Decision (Y), hypotheses testing is required. Path analysis methodology was used to construct the study's research model. Based on existing evidence, a hypothesis on the effect of price, Halal labeling and product suitability on purchasing decisions of cosmetics among female Muslim academicians was tested.

$$
Y=-0,081 X_{1}+0,406 X_{2}+0,307 X_{3}, \mathrm{R}^{2}=0,417
$$

First step is to test the hypotheses in general:

$H_{0}: R_{Y\left(X_{1} X_{2} X_{8}\right)}=0$; there is no significant effect of overall price, Halal labeling and product suitability to skin types all together on purchase decision.

$H_{1}: R_{Y\left(X_{1} X_{2} X_{8}\right)} \neq 0$; there is a significant effect of overall price, Halal labeling and product suitability to skin types all together on purchase decision

The formula used to test the hypotheses is F test formula : 


$$
F=\frac{(n-k-1) R_{X_{u}\left(X_{1} X_{2} \cdots X_{k}\right)}^{2}}{k\left(1-R_{X_{u}\left(X_{1} X_{2} \cdots X_{k}\right)}^{2}\right)}
$$

The above $\mathrm{F}$ Test formula following distribution table $F$-Snedecor with the degree of freedom $\mathrm{k}$ dan $\mathrm{n}-\mathrm{k}-1$. Testing criteria is rejecting the null hypothesis $\mathrm{H}_{0}$ if $\mathrm{F}_{\text {statistic }}>\mathrm{F}_{\text {table }}(\alpha ; \mathrm{k} ; \mathrm{n}-\mathrm{k}-1)$.

The value of $F$ Statistic for the first structural equation is as follow:

$$
F=\frac{(53-3-1)(0,417)}{3(1-0,417)}=11,683
$$

Referring to $\mathrm{F}$ distribution, thus $F_{\text {table }(0,05 ; 3 ; 53)}=2,78$. Since $\mathrm{F}_{\text {statistics }}>\mathrm{F}_{\text {table, }}$, hence $\mathrm{H}_{0}$ is rejected. Price, Halal Labeling, and Product Suitability to Skin Types all together has effect on the purchase decision, therefore the partial test is run.

T-test is then used for partial analysis of each sub-variables with the formula as follow:

$$
t=\frac{p_{X_{u} X_{i}}}{\sqrt{\frac{\left(1-R_{X_{u}}^{2}\left(X_{1} X_{2 \mathrm{~m}} X_{k}\right)\right) c_{i i}}{(n-k-1)}}} \quad ; \mathrm{u} \text { and } \mathrm{i}=1,2, \ldots, \mathrm{k}
$$

Statistical test above following distribution of $\mathrm{T}$ with the degree of freedom $=\mathrm{n}-\mathrm{k}-1$ and testing criteria $=$ reject null hypothesis $\mathrm{H} 0$ if Fstatistic $>$ Ftable $(\alpha ; \mathrm{n}-\mathrm{k}-1)$. By using statistical program SPSS 16.0 , the path coefficient with the testings is presented on table 13:

$$
\text { TABLE } 13 .
$$

PARTIAL TESTING OF PRICE, HALAL LABELING, AND PRODUCT SUITABILITY TO SKIN TYPES ON PURCHASE DECISION

\begin{tabular}{|c|l|l|l|l|}
\hline $\begin{array}{c}\text { Variabl } \\
\text { e }\end{array}$ & $\begin{array}{c}\text { Path } \\
\text { Coefficie } \\
\text { nt }\end{array}$ & $\begin{array}{l}\text { t- } \\
\text { statistic }\end{array}$ & $\begin{array}{l}\text { t- } \\
\text { table }\end{array}$ & Conclusion \\
\hline $\mathrm{PYX}_{1}$ & -0.081 & -0.687 & 2.00 & $\begin{array}{l}\mathrm{H}_{0} \text { accepted, there } \\
\text { is no real effect }\end{array}$ \\
\hline $\mathrm{PYX}_{2}$ & 0.406 & 3.084 & 2.00 & $\begin{array}{l}\mathrm{H}_{0} \text { rejected, there } \\
\text { is real effect }\end{array}$ \\
\hline $\mathrm{PYX}_{3}$ & 0.307 & 2.203 & 2.00 & $\begin{array}{l}\mathrm{H}_{0} \text { rejected, there } \\
\text { is real effect }\end{array}$ \\
\hline
\end{tabular}

Source: data collection and analysis

By using $\mathrm{T}$ distribution table, ${ }^{t_{(}\left(0,05 / 2^{; 53}\right)}=2,00$. Based on the computation on table 13, it is clear that not all Tstatistics > Ttable, this means that price does not indicate the real effect on purchase decision, Halal labeling and product suitability to skin types indicate the real effect on purchase decision.

\section{F. Hypothesis testing of Halal Labelling and Product Suitability to Skin Types on Purchase Decision.}

After trimming and analyzing, the structural equation was formed as follow:

$$
Y=0,389 X_{2}+0,342 X_{3}, \mathrm{R}^{2}=0,411
$$

First, the hypothesis was tested in overall:

$H_{0}: R_{Y\left(X_{2} X_{2}\right)}=0 \quad$; there is no significant effect of overall Halal label and product suitability to skin types all together on purchase decision

$H_{1}: R_{Y\left(X_{2} X_{8}\right)} \neq 0$; there is a significant effect of overall Halal label and product suitability to skin types all together on purchase decision

The formula used to test the hypotheses is $\mathrm{F}$ test formula:

$$
F=\frac{(n-k-1) R_{X_{u}\left(X_{1} X_{2} \cdots X_{k}\right)}^{2}}{k\left(1-R_{X_{u}\left(X_{1} X_{2} \cdots X_{k}\right)}^{2}\right)}
$$

The above $\mathrm{F}$ Test following distribution table $F$ Snedecor with the degree of freedom k and $\mathrm{n}-\mathrm{k}-$ 1. Testing criteria is rejecting the null hypothesis $\mathrm{H}_{0}$ if $\mathrm{F}_{\text {statistic }}>\mathrm{F}_{\text {table }}(\alpha ; \mathrm{k} ; \mathrm{n}-\mathrm{k}-1)$.

The value of $\mathrm{F}$ statistic for the first structural equation is:

$$
F=\frac{(53-2-1)(0,411)}{2(1-0,411)}=17,445
$$

By using $\mathrm{F}$ distribution table, $F_{\text {tabel }(0,05 ; 2 ; 53)}=3,17$. Since $F_{\text {statistics }}>F_{\text {table, hence }}$ $\mathrm{H}_{0}$ is rejected. Overall variables of Halal Labeling and Product suitability to skin types have real effect on purchase decision, thus partial testing can be continued.

T-test used for partial analysis of sub-variable with the formula as follow:

$$
t=\frac{p_{X_{U} X_{i}}}{\sqrt{\frac{\left(1-R_{X_{u}}^{2}\left[X_{1} X_{2 \mathrm{~m}} X_{k}\right)\right.}{(n-k-1)}}} ; \mathrm{u} \text { and } \mathrm{i}=1,2, \ldots, \mathrm{k}
$$

Statistical test above following distribution of $\mathrm{T}$ with the degree of freedom $=\mathrm{n}-\mathrm{k}-1$ and testing criteria $=$ reject null hypothesis $\mathrm{H}_{0}$ if $t_{\text {statistic }}>t_{\text {table }}$ $(\alpha ; \mathrm{n}-\mathrm{k}-1)$. 
The following is the testing of path coefficient.

TABLE 14.

PARTIAL TESTING THE EFFECT OF HALAL LABELING AND PRODUCT SUITABILITY TO SKIN TYPES ON PURCHASE DECISION

\begin{tabular}{|l|c|l|l|l|}
\hline Variable & $\begin{array}{c}\text { Path } \\
\text { Coefficient }\end{array}$ & $\begin{array}{l}\text { t- } \\
\text { statistic }\end{array}$ & $\begin{array}{l}\text { t- } \\
\text { table }\end{array}$ & Conclusion \\
\hline $\mathrm{PYX}_{2}$ & 0,389 & 3,024 & 2,00 & $\begin{array}{l}\mathrm{H}_{0} \text { rejected, } \\
\text { there is real } \\
\text { effect }\end{array}$ \\
\hline $\mathrm{PYX}_{3}$ & 0,342 & 2,661 & 2,00 & $\begin{array}{l}\mathrm{H}_{0} \text { rejected, } \\
\text { there is real } \\
\text { effect }\end{array}$ \\
\hline
\end{tabular}

Source: data collection and analysis

By using $\mathrm{T}$ distribution table, ${ }^{t_{\left(0,05 / 2^{;} 53\right)}}=2,00$. Based on the computation on table 14 , it is clear that all $t_{\text {statistic }}>t_{\text {table. This means that variable Halal }}$ labeling and Product suitability to skin types indicate the real effect on purchase decision. With the formula $\varepsilon_{2}=1-R^{2}=1-0,411=0,589$ meaning that the effect of other variables outside the model on purchase decision is 0,589 .

Out of 3 analyzed variables price, Halal labeling, and product suitability to skin types, the finding reveals only Halal labeling $\left(\mathrm{X}_{2}\right)$ and product suitability to skin types $\left(\mathrm{X}_{3}\right)$, indicate the real effect on purchase decision (Y) of cosmetics products among female Muslim academicians.

G. Significance Testing of Correlation Coefficient between variable Halal Labelling and Product Suitability to Skin Types.

The hypothesis is as follow:

$H_{0}:{ }^{\rho_{X_{i} X_{j}}=0}$; there is no real effect

$H_{1}: \rho_{X_{i} X_{j}} \neq 0$; there is real effect

$\mathrm{T}$ test used to examine the significance of coefficient correllation with the formula:

$$
t=r \sqrt{\frac{n-2}{1-r^{2}}}
$$

Statistical test above following distribution of $\mathrm{T}$ with the degree of freedom $=\mathrm{n}-\mathrm{k}-1$ and testing criteria $=$ reject null hypothesis $H_{0}$ if $\mathrm{t}_{\text {statistic }}>\mathrm{t}_{\text {table }}(\alpha$; n-k-1).

Furthermore, the result significant testing of correlation coefficient on Halal Labeling $\left(\mathrm{X}_{2}\right)$ and Product Suitability on Skin Types $\left(\mathrm{X}_{3}\right)$, is as follow:
TESTING CAUSAL RELATIONSHIP BETWEEN EXOGENOUS VARIABLES

\begin{tabular}{|l|l|l|l|l|}
\hline Variable & $\begin{array}{l}\text { Correlation } \\
\text { Coefficient }\end{array}$ & t-statistic & t-table & Conclusion \\
\hline $\mathbf{r} \mathbf{x}_{\mathbf{2}} \mathbf{X}_{\mathbf{3}}$ & 0,537 & 4,55 & 1.98 & $\begin{array}{l}\mathrm{H}_{0} \text { rejected, there is } \\
\text { real correlation }\end{array}$ \\
\hline
\end{tabular}

Referring to the $\mathrm{T}$ distribution table $\mathrm{t}_{\left(0,05 / 2^{153}\right)}=$ 2,00 , and $\mathrm{t}$ statistic on the table 15 is greater than $\mathrm{t}$ table. Thus, it can be concluded that there is real correlation between Halal labeling $\left(\mathrm{X}_{2}\right)$ and product suitability to skin types $\left(\mathrm{X}_{3}\right)$.

\section{H. Contribution of Variables Halal Labelling and Product \\ Suitability to Skin Types on Purchase Decision.}

The following formulae used in computing the magnitude of real and direct effect, indirect effect and the effect of total exogenous variables on endogenous variable partially:

- The magnitude of direct effect of exogenous variables on endogenous variable $=P_{X_{n} X_{i}} \times P_{X_{n} X_{i}}$

- The magnitude of indirect effect of exogenous variables on endogenous variable $=P_{X_{u} X_{i}} \times r_{X_{i} X_{j}} \times P_{X_{u} X_{j}}$

- The magnitude of all of exogenous variables on endogenous variable is the sum of the magnitude of direct and indirect effect $=\left[P_{X_{u} X_{i}} \times P_{X_{u} X_{i}}\right]+\left[P_{X_{u} X_{i}} \times r_{X_{i} X_{j}} \times P_{X_{u} X_{j}}\right]$

\section{Contribution of Halal Label and Product Suitability to} Skin Types on Purchase Decision

Based on the previous calculations, it is revealed that the contribution of Halal labeling to purchase decision through Product suitability to skin types is valued $7,14 \%$. This means that Halal label has greater direct effect on purchase decision as compared to joined with product suitability to skin types. In total, the contribution of Halal Label on purchase decision reached $22,27 \%$.

TABEL16.

DIRECT AND INDIRECT EFFECT OF HALAL LABELING $\left(\mathrm{X}_{2}\right) \mathrm{ON}$ PURCHASE DECISION (Y)

\begin{tabular}{|l|l|l|}
\hline Path Analysis Interpretation & Effect & $\%$ \\
\hline Direct effect to Y & 0.1513 & $15.13 \%$ \\
\hline Indirect effect through $\mathrm{X}_{3}$ to Y & 0.0714 & $7.14 \%$ \\
\hline Total & $22.27 \%$ \\
\hline
\end{tabular}


The contribution of Product Suitability to Skin Types on purchase decision is presented on the table 17 below:

TABLE 17

DIRECT AND INDIRECT EFFECT OF PRODUCT SUITABILITY TO SKIN TYPES $\left(\mathrm{X}_{3}\right)$ ON PURCHASE DECISION (Y)

\begin{tabular}{|l|l|l|}
\hline Path Analysis Interpretation & Effect & $\%$ \\
\hline Direct effect to Y & 0.117 & $11.7 \%$ \\
\hline Indirect effect through $\mathrm{X}_{2}$ to $\mathrm{Y}$ & 0.0714 & $7.14 \%$ \\
\hline Total & & $18.84 \%$ \\
\hline
\end{tabular}

From table 17, it is revealed that direct contribution of Product Suitability to Skin Types to purchase decision is valued $11.7 \%$, and the contribution of Product Suitability to Skin Types on Purchase Decision through Halal labeling is valued 7.14\%. This means that Product Suitability to Skin Types has greater direct effect on purchase decision as compared to joined with Halal labeling. In total, the contribution of Product Suitability to Skin Types on purchase decision reached $18.84 \%$.

Based on table 18, Halal Labeling and Product Suitability to Skin Types give positif contribution on purchase decision whereas Halal labeling give greatest contribution.

TABLE 18

TOTAL EFFECT OF HALAL LABEL AND PRODUCT SUITABILITY TO SKIN TYPES ON PURCHASE DECISION

\begin{tabular}{|l|l|}
\hline Variable & Effect (\%) \\
\hline Halal Labeling $\left(\mathrm{X}_{2}\right)$ & $22,27 \%$ \\
\hline Product Suitability to Skin Types $\left(\mathrm{X}_{3}\right)$ & $18,84 \%$ \\
\hline
\end{tabular}

\section{CONCLUSION AND EXPECTED FINDING IMPLICATIONS}

All other things remaining the same, price is a major determinant of demand. However, factors such as religious considerations and necessity tend to dilute the effect of price on purchasing decisions as the case in the present study. There are a couple plausible explanations on the observed limited influence of price. Firstly, price is viewed relative to income. As disposable income increases with occupation, prices of some products and services appear relatively lower. Similarly, the influence of price diminishes when products are consumed for their necessity. Grooming is an important aspect of most formal middle class occupations as academia. Furthermore, the low influence of price on consumption decisions could be attributed to aspirational consumption. As circumstances and living standards improve, consumers tend to seek to satiate their wants formed during prior periods.

This case study also revealed that educated middle class female Muslims in Indonesia attach a higher value on religious acceptability. Religious appropriateness of products ranks higher than price in the purchasing decision matrix. Stated otherwise, consumers are willing to purchase appropriate products at seemingly higher prices. The demand for appropriate products could be attributed to awareness, either arising from access to formal education or as a result of religious campaigns. Similarly, consumers also seek products that are suitable for their respective skin types and as a result place lesser significance on price.

Findings from this study ought to be interpreted within some limitations. The study was based on a small sample, did not cover all regions of Indonesia and was limited to female Muslim academics. Notwithstanding these limitations, findings from the study are insightful and have implications for the cosmetics industry in Indonesia and countries with similar socio-demographic attributes. Improving access to formal education and the subsequent increase in female participation in formal employment improves their need and social standing that influence their consumption patterns. Producers also need to ensure that their products are acceptable in societies they operate in and are appropriately labeled and adhere to religious standards. Finally, it is critical for cosmetics producers to invest in research and development. This would ensure the production of acceptable, suitable and effective cosmetics.

\section{ACKNOWLEDGMENT}

Researchers of this study wish to thank to Economics Development Department and Management Department, of Faculty of Economics, Siliwangi University for the support.

\section{REFERENCES}

[1] S. Alhedhaif, U. Lele, and B. A. Kaifi, "Brand Loyalty and Factors Affecting Cosmetics Buying Behavior of Saudi Female Consumers," J. Bus. Stud. Q., vol. 7, no. 3, p. 2152, 2016.

[2] [2] K. H. Hanzaee and L. Andervazh, "The Influence of Brand Loyalty on Cosmetics purchase Intention of Iranian Female Consumers Brand loyalty :," vol. 2, no. 5, pp. 5389-5398, 2012. 
[3] [3] A. Mukhtar and M. Mohsin Butt, "Intention to choose Halal products: the role of religiosity," J. Islam. Mark., vol. 3, no. 2, pp. 108120, 2012.

[4] [4] A. N. Ahmad, A. A. Rahman, and S. A. Rahman, "Assessing Knowledge and Religiosity on Consumer Behavior towards Halal Food and Cosmetic Products," Int. J. Soc. Sci. Humanit., vol. 5, no. 1, pp. $10-14,2015$.

[5] [5] P. Teng and W. J. W. Jusoh, "Investigating Students Awareness and Usage Intention Towards Halal Labelled Cosmetics and Personal Care Products in," 4th Int. Conf. Bus. Econ. Res. (4th ICBER 2013) Proceeding, no. March, pp. 367-376, 2013.

[6] [6] Noreen Noor Abd Aziz and Eta Wahab, "Understanding of Halal Cosmetics Products : TPB Model,” pp. 1-6, 2013.

[7] [7] A. J. bt C. M. Hashim and R. Musa, "Factors Influencing Attitude towards Halal Cosmetic among Young Adult Urban Muslim Women: A Focus Group Analysis," Procedia - Soc. Behav. Sci., vol. 130, no. May 2014, pp. 129-134, 2014.
[8] [8] Z. Z. Suhana Mohezar, Suhaiza Zailani, "Halal Cosmetics Adoption Among Young Muslim Consumers in Malaysia: Religiosity Concern," Procedia - Soc. Behav. Sci., vol. 6, no. 1, pp. 47-60, 2016.

[9] [9] M. B. Majid, I. Sabir, and T. Ashraf, "Consumer Purchase Intention towards Halal Cosmetics \& Personal Care Products in Pakistan," vol. 1, no. 1, pp. 45-53, 2015.

[10] [10] V. Briliana and R. Noviana, "The antecedents and outcome of Halal cosmetic products: a case study in jakarta indonesia," vol. 11, no. 2, pp. 1-9, 2016.

[11] [11] M. Aisyah, "Consumer Demand on Halal Cosmetics and Personal Care Products in Indonesia," Al-Iqtishad J. Islam. Econ., vol. 9, no. 1, 2016

[12] [12] P. Economics, "Available online at www.sciencedirect.com," vol 31 , no. 15 , pp. 325-332, 2015.

[13] [13]R. Azizpour, T. Abbasnejad, and M. Siyavooshi, "Effective Factors on Purchasing Intention of Cosmetics and Health Products in Tehran City," Int. J. Acad. Res. Bus. Soc. Sci., vol. 6, no. 11, pp. 449 458, 2016. 